\title{
Ceramics in Environmental Catalysis: Applications and Possibilities
}

\author{
Nitin LABHSETWAR ${ }^{1, *}$, P. DOGGALI ${ }^{1}$, S. RAYALU ${ }^{1}$, R. YADAV $^{1}$, T. MISTUHASHI ${ }^{2}$, H. HANEDA $^{2}$ \\ ${ }^{1}$ Environmental Material Division, National Environmental Engineering Research Institute (CSIR-NEERI), Nehru Marg, \\ Nagpur 440020, India \\ ${ }^{2}$ National Institute for Materials Science (NIMS), Namiki, Tsukuba, Ibaraki 3050044, Japan
}

\begin{abstract}
Environmental catalysis has been steadily growing because of the advances in its scientific and engineering aspects, as well as due to the new environmental challenges in the industrial era. The development of new catalysts and materials is essential for new technologies for various environmental applications. Ceramics play important roles in various environmental applications including the identification, monitoring, and quantification of pollutants and their control. Ceramics have important applications as sensors and photocatalysts, and they are extensively used as catalyst carriers and supports. Many ceramics are being explored as catalysts for pollution control applications. Their low cost, thermal and chemical stability, and capability of being tailored make them especially attractive for pollution control applications. Although a wide variety of materials have been developed as catalyst supports, this area is still of interest with new or modified catalyst supports being frequently reported. It is of equal importance to develop new or modified processes for the loading of catalysts on specific supports. Applications like chemical looping combustion (CLC) and other catalytic combustion processes are raising the demands to a new scale. We have been working on the development of both new and modified support materials, including mesoporous materials without structural order for possible applications in CLC and other catalytic reactions. Successful attempts have been made in the modification of conventional $\gamma-\mathrm{Al}_{2} \mathrm{O}_{3}$ and improved synthesis processes for supporting perovskite type catalysts. Our research on environmental catalysis applications of ceramic materials and processes are also briefly discussed.
\end{abstract}

Key words: ceramics; environmental catalysis; perovskite catalyst; carbonation; catalyst support; catalytic emission control; chemical looping combustion

CLC number: O643 Document code: A

Received 7 May 2012. Accepted 26 July 2012.

*Corresponding author. Tel: +91-712-2247828; Fax: +91-712-2247828; E-mail: nk_labhsetwar@neeri.res.in

English edition available online at Elsevier ScienceDirect (http://www.sciencedirect.com/science/journal/18722067).

With the increasing challenges of new pollutants and their complex interactions that further lead to a range of secondary pollutants, it is imperative to develop new multifunctional materials to effectively detect, quantify, and control these environmental pollutants. Ceramic processes and ceramic materials represent a very wide range of materials extensively used in many environmental applications. Intensive research have been carried out in different parts of the world to develop ceramic supports/substrates, ceramic carriers, and other structures that have a wide range of properties and specifications including cell density, porosity, and wall configurations. Thermal properties (resistant to thermal shocks, refractoriness, stability), strength, chemical stability, lightness in weight, flexibility in chemical composition, and low cost have made ceramic materials the best catalyst supports for many important reactions in environmental and energy applications [1-3]. Ceramics have also been recognized as environmentally safe materials, which further add to their potential. Efforts are also being made to synthesize ceramics with minimum energy inputs to lower their greenhouse gas (GHG) footprints. Significant advances have been achieved in the improved synthesis of ceramics.

Environmental catalysis is an effective option for the control of several challenging air pollutants. Although the catalyst is often referred to as heart of the catalytic process, most catalysts are used in supported form to achieve improved physical properties, stability, and often even improved activity through catalyst-support interactions. Although there are a number of unsupported catalysts used in industrial processes, most environmental catalysts are used in supported form. Two terms are commonly used-carrier, which is usually a high surface area material to disperse the catalyst for achieving maximum activity (Fig. 1), and support or substrate, which is usually a structure used for the final application of the catalyst. The carrier material generally has a complex microstructure to give high surface area and effective mass transfer rates for gas phase reactants. Its primary role is to disperse the fine catalyst for their effective use, as well as to provide the requisite stability for a specific application. Obviously, the choice and properties of the carrier depend on a specific application. However, a limited number of catalyst carriers are most commonly used 


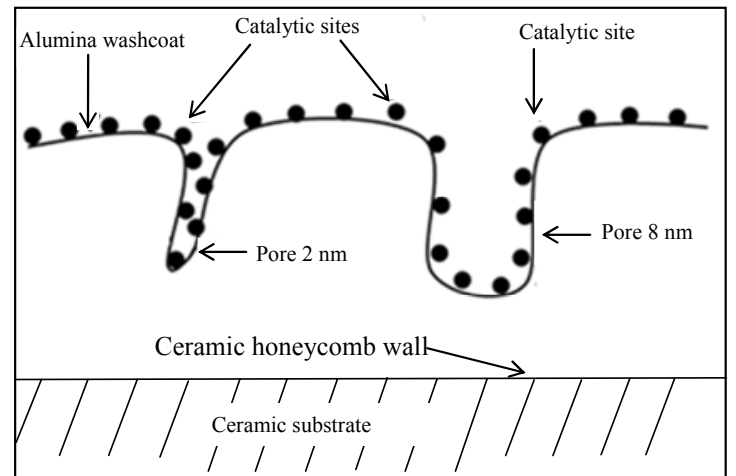

Fig. 1. Conceptual picture of catalytic sites dispersed on a high-surface-area $\mathrm{Al}_{2} \mathrm{O}_{3}$ carrier coated onto a monolith [4].

for environmental applications. The carriers also provide useful catalyst-carrier interactions that influence the catalytic properties.

This property is exploited to develop new and modified catalysts. Commonly used catalyst carriers are inorganic oxide based materials like alumina, silica, titania, zirconia, zeolites, and other ceramics [4]. Alumina has been the most commonly used carrier for environmental catalysts. This material is available in different phases determined by thermal history, preparation method, purity, and water/hydroxyl content. The most commonly used phase is the $\gamma$-monohydrate phase, which is stable in the temperature range of $500-850{ }^{\circ} \mathrm{C}$. The high surface area of this phase is generated by the controlled calcination of the boehmite phase in air at above $500{ }^{\circ} \mathrm{C}$. A network of alumina particles (2-5 nm size) is formed that leads to polymer chains with a specific surface area in the range of $100-250 \mathrm{~m}^{2} / \mathrm{g}$. A range of new materials have been developed, including hydrothermally stable zeolites, mesoporous materials, and high surface area ceria [5-7]. Some of these materials have already found practical applications in specific catalytic processes. We recently found that materials with meso-sized pores but without an ordering of its structure were very useful for many gas phase reactions. This was mainly due to their high surface areas and improved mass transfer properties. The absence of ordering also sometimes gives better mechanical and thermal stability.

Ceramic supports/substrates have been an essential part of environmental catalysts for mobile as well as stationary applications. Advances have been achieved in the development of the ceramic honeycomb and other designed structures using mulite, alumina, cordierite and other ceramic compositions [8]. Ceramic monoliths used as the catalyst support in a three way catalytic converter consist of a closely packed array of small square cells. The cell surface of the honeycomb is often coated with fine alumina particles and the precious metal catalysts are dispersed on the surface of these particles [9]. Ceramics such as silicon carbide are being explored as a substitute material for making a diesel particulate filter (Fig. 2) because of its high thermal stability and conductivity, which are advantageous for reducing the local temperature gradient [10].

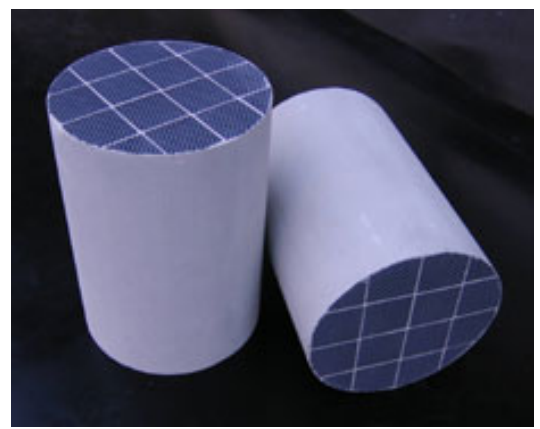

Fig. 2. Silicon carbide diesel particulate filter. (http://www.ceramic-honeycombs.com)

Ceramic-based oxygen sensors are commonly used to control the air/fuel ratio in the operation of three-way catalysts for automobile exhaust applications. The oxygen sensors usually consist of a solid state electrode made of zirconia-based ceramics. A range of other ceramic-based sensors have also been developed for various industrial and environmental applications. The chemical and thermal stability of these ceria-based and other ceramic sensors make them suitable for use under the harsh conditions of automobile exhaust and industrial off-gases. Inorganic oxides with semiconductor properties are the most frequently used materials for sensing applications. These can often be referred as ceramic materials.

Ceramic synthesis processes have also been frequently used for catalyst preparation. A still challenging area of research is the loading of a catalyst onto a ceramic support without affecting its properties. Perovskites and several other mixed oxides have been studied for several decades as low cost catalysts for environmental applications. Their high temperature synthesis has been a subject of intense research by many groups, including our group [11-15]. New ceramic supports with improved pore structures are being developed to support such catalysts, and it is of importance to exploit the various synthesis methods to improve their physical properties like specific surface area. As mentioned above, a low cost template method has been recently developed using a natural biopolymer to synthesize titania, ceria, zirconia, baria, and other materials with improved surface area and pore structure [16]. These improved materials have been used for supporting catalysts for $\mathrm{CO}$ oxidation, VOCs oxidation, methane combustion, and $\mathrm{N}_{2} \mathrm{O}$ (nitrous oxide) decomposition. Supported perovskites on commercially available ceramic and other supports were synthesized to improve their low temperature catalytic activity for environmental applications. We were able to mod- 
ify $\gamma-\mathrm{Al}_{2} \mathrm{O}_{3}$ and other carriers for perovskite applications [15]. Some details are discussed in subsequent parts of this article.

Thermally stable zeolites with a high $\mathrm{SiO}_{2} / \mathrm{Al}_{2} \mathrm{O}_{3}$ ratio can be easily supported because the carrier on the ceramic honeycombs has compositional compatibility. Metal incorporated zeolites are being explored in our group as catalysts for $\mathrm{N}_{2} \mathrm{O}$ decomposition and other reactions. The metal exchanged (bimetallic) zeolites synthesized by ion exchange showed excellent catalytic activity for this reaction [17,18].

Ceramics are also potential materials for $\mathrm{CO}_{2}$ capture and sequestration. The mineral carbonation process is effective for $\mathrm{CO}_{2}$ sequestration, while biomineralization is also being explored for mimicking some of the biological processes important for $\mathrm{CO}_{2}$ sequestration [19-22].

The following sections describe works on ceramic catalyst supports, ceramic synthesis methods, and their applications to reactions of environmental importance.

\section{Perovskites in environmental catalysis}

Mixed oxides with the perovskite structure have the potential catalytic properties for widespread applications. Perovskites are binary oxides with the general formula $\mathrm{ABO}_{3}$. The availability of a large number of cations that can fit in both $\mathrm{A}$ and $\mathrm{B}$ positions offer the perovskite structure a highly versatile flexibility in their chemical composition. Their structure and properties can be modified by substitution at both A and B sites. As described by Pena et al. [23], the diverse properties of these compounds are due to that around $90 \%$ of the metallic elements of the periodic table are stable in a perovskite structure. This gives the possibility of synthesizing multi-component perovskites by the partial substitution of cations in positions $\mathrm{A}$ and $\mathrm{B}$ giving compounds with the formula $\mathrm{A}_{1-x} \mathrm{~A}_{\dot{\alpha} x} \mathrm{~B}_{1-x} \mathrm{~B}_{\dot{\alpha} x} \mathrm{O}_{3}$. The oxygen absorption and desorption properties of perovskites play a crucial role in the low temperature oxidation of soot/particulates.

The low cost of a catalyst is a criterion for its practical application. This is especially important in environmental catalysis. In our search for low cost catalysts, mainly for automobile exhaust treatment, we have extensively studied perovskites and other mixed oxides for $\mathrm{CO}, \mathrm{HC}$ (hydrocarbon), and $\mathrm{NO}_{x}$ (nitrogen oxides) control. Although perovskites have been frequently reported as potential substitutes for noble metal-based two/three-way catalysts, their practical applications have been limited. While high thermal stability and low cost are the distinct advantages of these catalysts, their poor chemical stability and low surface area remain serious limitations. This is because the ceramic route is the most commonly used synthesis method to obtain pure phase perovskites. Recently, many attempts have been made to prepare supported perovskites, which has resulted in remarkable improvements in their surface area such that they begin to have practical value. Perovskites are therefore extensively investigated for a range of catalytic reactions of environmental importance, including $\mathrm{CO}$ oxidation, $\mathrm{HC}$ oxidation, methane combustion, partial oxidation and oxidative coupling of methane, $\mathrm{CO}$ and $\mathrm{CO}_{2}$ hydrogenation, $\mathrm{NO}_{x}$ reduction, $\mathrm{N}_{2} \mathrm{O}$ decomposition, diesel soot oxidation, VOC (volatile organic compound) oxidation, environmental photocatalysis, methane reforming, and several reactions for green synthesis [24-29]. Their uses in chemical sensors and electrocatalysts are also frequently reported.

A range of perovskites, mixed oxides and other low cost catalysts including substituted, promoted, and supported perovskites have been designed and synthesized using various techniques. We have been working on ceramic honeycombs coated with non-noble metal based perovskites and other catalysts for automotive applications [30-32]. It was possible to stabilize ruthenium in the perovskite structure using ceramic synthesis processes. The synthesis of $\mathrm{LaRuO}_{3}$ using different synthesis methods gave improvements in the physical and catalytic properties of these ruthenium-based materials, and it is possible to stabilize $\mathrm{Ru}$ in the 3+ oxidation state [33]. Efforts have been made to synthesize perovskites with ruthenium in the more stable 4+ oxidation state $\left(\mathrm{La}_{3.5} \mathrm{Ru}_{4.0} \mathrm{O}_{13}\right)$ using various techniques. This material shows high thermal stability above $1100{ }^{\circ} \mathrm{C}$ and it was studied for catalytic methane combustion [34] and diesel soot oxidation [35]. Recently, we have investigated the catalytic activity of this material for $\mathrm{CO}$ (carbon monoxide) oxidation in the presence of co-existing gases like a low concentration of $\mathrm{SO}_{2}, \mathrm{CO}_{2}$, and water [36]. In our studies, Ce substituted/promoted $\mathrm{SrCoO}_{3}$ prepared by ceramic and other methods showed high catalytic activity for diesel soot oxidation. The soot oxidation activity of $\mathrm{Sr}_{0.8} \mathrm{Ce}_{0.2} \mathrm{CoO}_{3}$ was observable at a temperature as low as $241{ }^{\circ} \mathrm{C}$ under some conditions [37]. We have used zirconia and titania supports with different transition metals. These catalysts have been studied for different reactions of environmental importance $[16,35,38]$. We are now exploring perovskites and other non-noble metal based catalysts supported on various type of ceramics for the control of emissions from biomass based fuels used in stoves for cooking and heating in rural areas of developing countries [39].

\section{Development of perovskites supported on ceramics}

A high synthesis temperature is required for perovskite synthesis, and so these are usually formed as a sintered crystalline phase with a large particle size and very low surface area, typically in the range of $1-4 \mathrm{~m}^{2} / \mathrm{g}$, which are 
not suitable for a practical catalyst. It is therefore important to modify both perovskite synthesis and the commonly used $\gamma-\mathrm{Al}_{2} \mathrm{O}_{3}$ washcoat support to synthesize supported perovskites. We have carried out detailed studies on the preparation of supported perovskites with a view to improve their specific surface area and to make them suitable for various commonly available cordierite supports and alumina. A range of perovskites with different compositions have been synthesized, and modified synthesis methods have been developed to support them using modified alumina and ceramic honeycomb substrates.

We have attempted various synthesis techniques including combustion synthesis, deposition precipitation, hot isobaric pressure (HIP) synthesis, co-precipitation, sol-gel synthesis, etc, depending on the specific application, to achieve high specific surface areas or crystallinity, and purity of the perovskite material [33]. However, these methods give only moderate improvements in the specific surface area, and it is almost essential to support these perovskite materials for high space velocity applications. These materials have been characterized in detail and their catalytic activity has been evaluated for various reactions of environmental importance. It was also possible to directly synthesize the catalysts on commercially available ceramic supports including those with a complex ceramic structures like the diesel particulate filter (DPF).

$\operatorname{Pr}_{(1-x)} \mathrm{A}_{(x)} \mathrm{B}_{(1-y)} \mathrm{O}_{3}$ ('A' represents the substitution element while ' $\mathrm{B}$ ' represents a transitional metal ion) compositions have been synthesized in both unsupported and supported forms by three different methods: co-precipitation, in situ synthesis on alumina pre-coated with praseodymium oxide, and synthesis of catalyst on praseodymium oxide pre-coated alumina using a "deposition precipitation" method.

In the co-precipitation method, mixed metal hydroxides were co-precipitated using aqueous ammonia. The precipitate was washed, oven dried and subsequently heated at 800 ${ }^{\circ} \mathrm{C}$ to obtain the perovskite phase using a reported procedure [33]. The supported catalyst was prepared in situ on alumina pre-coated with praseodymium oxide (Pr-O). Approximately $10 \mathrm{wt} \%$ praseodymium oxide was loaded on commercial gamma alumina (Sasol) using wet impregnation. The alumina powder was suspended in an aqueous solution of praseodymium salt, filtered, oven dried, and heated in air at $800{ }^{\circ} \mathrm{C}$ for $4 \mathrm{~h}$. This cycle was repeated a few times to achieve the desired loading. Finally, the material was heated in air at $900{ }^{\circ} \mathrm{C}$ for $10 \mathrm{~h}$. An in situ sample of an alumina supported perovskite catalyst was prepared by the wet impregnation of praseodymium oxide pre-coated alumina with a precursor mixed metal ion solution and subsequent heating at $900{ }^{\circ} \mathrm{C}$ for $8 \mathrm{~h}$. This procedure was repeated to obtain $10 \mathrm{wt} \%$ catalyst loading. In yet another method, the catalyst was prepared following the deposition-precipitation method described by Cimino et al. [40]. In situ synthesis of the catalyst gives the best dispersion on the alumina washcoat. The only problem with this method is that the perovskite precursors react with alumina to form undesired phases including spinels. However, a suitable pre-coat on the alumina prevents this to a large extent. The deposition-precipitation method offers a relatively high dispersion with good purity of perovskite material on substrate.

We have observed that alumina pre-calcined at a higher temperature (about $950{ }^{\circ} \mathrm{C}$ ) is better for perovskite applications because of its suppressed reactivity and pore structure. As shown in many previous attempts and also from the considering of its obvious reactivity, the preparation of perovskites directly on alumina almost always leads to the formation of many undesired phases, which makes it difficult to get the targeted perovskite phase. A pre-coat of a suitable material is therefore essential for supporting the perovskite on alumina. The pre-coat material, pre-coat loading, and pre-coat technique are the important parameters. The pre-coat material should be selected by considering the composition of the perovskite to be supported: lanthanum and cerium oxides were found appropriate for many of our preparations. The $\operatorname{Pr}_{2} \mathrm{O}_{3}$-based pre-coat of the present study was used to synthesize the praseodymium-based catalyst compositions. In general, a pre-coat of an oxide of the 'A' site cation of the perovskite composition is the best for the preparation of supported perovskites.

Ceramic honeycomb supported praseodymium-based perovskite catalysts have also been synthesized. Honeycomb supports with 400 cpsi cell density and wall thickness of approximately $0.15 \mathrm{~mm}$ were used. The initial porosity of these supports was in the range of $35 \%-40 \%$ with an open frontal area of $65 \%-78 \%$. The supported $\operatorname{Pr}$ based perovskites were prepared by the following two steps. (i) Pre-coating of praseodymium oxide by in situ precipitation (approximately $5 \mathrm{wt} \%$ referred to the monolith mass). In this pre-coating process, the support was soaked in the precipitate slurry of praseodymium and transitional metal hydroxides, and dried by a hot air gun. This process was repeated several times to obtain the desired loading of the catalyst. The coated supports obtained were calcined at 500 ${ }^{\circ} \mathrm{C}$ for $4 \mathrm{~h}$. (ii) Subsequent catalyst coating on the support (approximately $5 \mathrm{wt} \%$ referred to the monolith mass) by in situ co-precipitation, using a similar procedure to that used for the pre-coating of praseodymium oxide. Finally, the support was calcined at $850{ }^{\circ} \mathrm{C}$ for $8 \mathrm{~h}$ to obtain the supported perovskite phase.

\section{Catalytic activity of supported perovskite and other catalysts}

In order to study and establish the advantages of sup- 
ported perovskites, extensive catalytic evaluation have been carried out on the supported praseodymium-based perovskites and several other catalysts. The catalytic reactions were usually carried out in a fixed bed, steady state gas phase reactor. The catalyst sample was placed in a quartz reactor for the catalytic run. Prior to the catalytic activity test, the catalysts were pretreated at $200-300{ }^{\circ} \mathrm{C}$ for $1 \mathrm{~h}$ in a flow of helium for surface cleaning. The flow rate of feed gases was measured by mass flow controllers (Alborg, USA). The space velocity was varied to give gas hourly space velocities of 7000, 20000, 28000, 45000, and $75000 \mathrm{~h}^{-1}$ depending on the target application. After the catalyst has attained steady state after a period of $30 \mathrm{~min}$ at each temperature, the effluent gas was analyzed by a gas chromatograph (SHIMADZU 2014 and Perkin Elmer Clarus 500) using a molecular sieve 5A column (for the analysis of $\mathrm{O}_{2}, \mathrm{CO}$, and $\mathrm{N}_{2}$ ) and a Porapak column (for the analysis $\mathrm{CO}_{2}$ ) and a chemiluminiscence based $\mathrm{NO}_{x}$ analyzer (Environment SA). Figures 3 and 4 depict the activities of honeycomb supported Pr perovskites for $\mathrm{CO}$ oxidation and soot oxidation. $\mathrm{CO}$ oxidation of $100 \%$ was observed at $220{ }^{\circ} \mathrm{C}$, while soot oxidation activity was observed at as low as 390 ${ }^{\circ} \mathrm{C}$. These were good activities under the experimental conditions used.

As already mentioned, we have also studied other perovskite phases in supported form including $\mathrm{La}_{3.5} \mathrm{Ru}_{4.0} \mathrm{O}_{13}$ [35]. Excellent thermal stability for the ruthenium in perovskite was attained by optimizing the perovskite composition. The significant catalytic properties shown by the resulting composition $\left(\mathrm{La}_{3.5} \mathrm{Ru}_{4.0} \mathrm{O}_{13}\right)$ led us to synthesize alumina and cordierite supported $\mathrm{La}_{3.5} \mathrm{Ru}_{4.0} \mathrm{O}_{13}$ using in situ co-precipitation as well as deposition-precipitation methods. These supported materials show remarkable improvements in surface areas and good activities for methane combustion. Figure 5 shows the data for alumina supported $\mathrm{La}_{3.5} \mathrm{Ru}_{4.0} \mathrm{O}_{13}$ for methane combustion, which shows that the $T_{50}$ and $T_{90}$

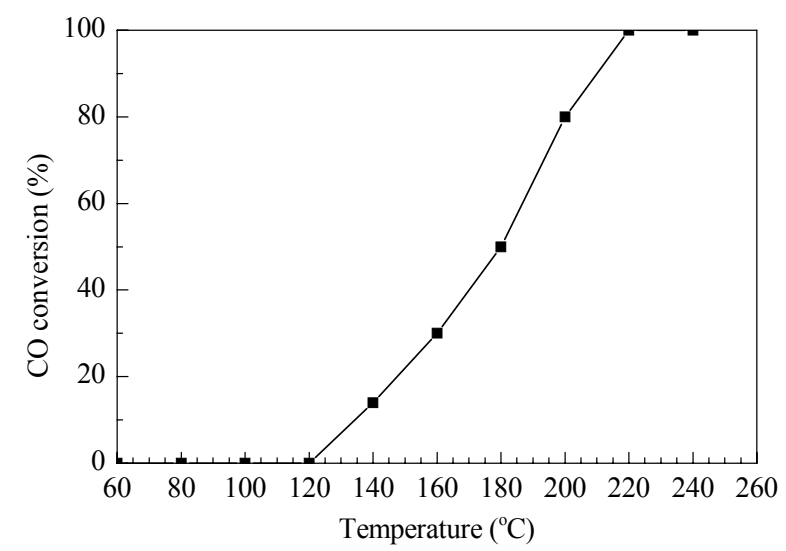

Fig. 3. Catalytic activity of supported praseodymium-based perovskite catalyst for $\mathrm{CO}$ oxidation. Reaction conditions: $0.2 \% \mathrm{CO}$, $10 \% \mathrm{O}_{2}$, He balance, space velocity $20000 \mathrm{~h}^{-1}$.

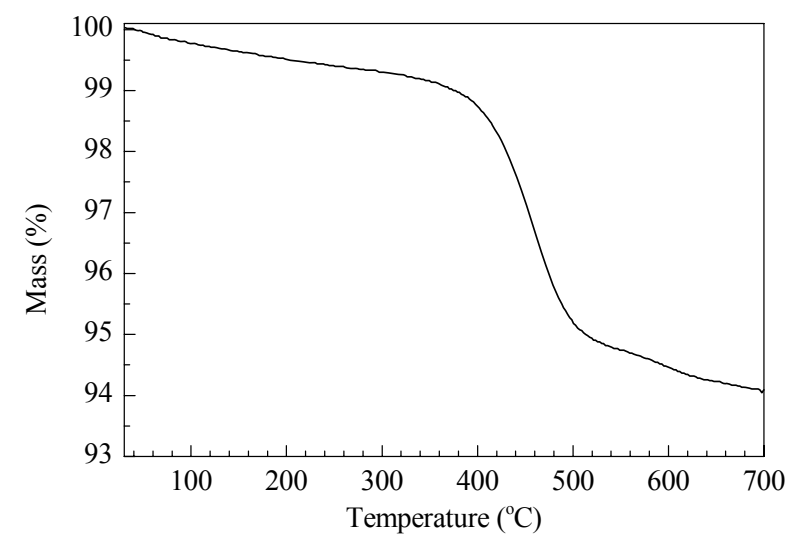

Fig. 4. Catalytic activity of supported praseodymium-based perovskite catalyst for soot oxidation. Reaction conditions: loose contact condition, catalyst: soot ratio $=95: 5$.

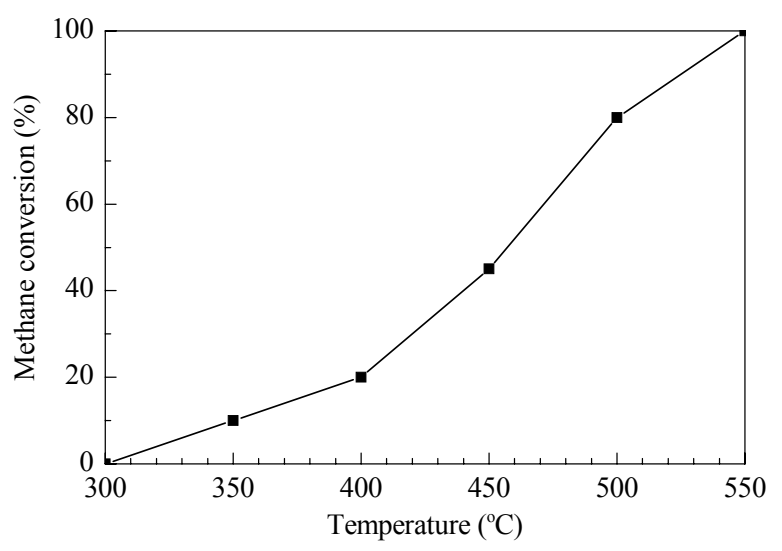

Fig. 5. Catalytic activity of supported perovskite catalyst for methane oxidation. Reaction conditions: $1.5 \% \mathrm{CH}_{4}, 18 \% \mathrm{O}_{2}, \mathrm{He}$ balance, space velocity $15000 \mathrm{~h}^{-1}$.

values for $\mathrm{La}_{3.5} \mathrm{Ru}_{4.0} \mathrm{O}_{13}$ were 450 and $550{ }^{\circ} \mathrm{C}$, respectively.

Zeolite based bimetallic catalysts supported on a cordierite honeycomb have also been synthesized and studied for $\mathrm{N}_{2} \mathrm{O}$ decomposition. Figure 6 illustrates the $\mathrm{N}_{2} \mathrm{O}$ decomposition activity over bimetallic USY-based catalysts. The ceramic supports were suitable for the zeolites because of their chemical compatibility, and honeycomb structures are now extensively used for supporting zeolites.

We have also explored zirconia as a catalyst support. The zirconia supported bimetallic catalysts showed good activity for carbon/soot oxidation [35]. The TG results of carbon/soot oxidation for bare zirconia and bimetallic zirconia are shown in Table 1, which showed the high catalytic activity of these materials.

Thermal stability experiments have been performed on these catalysts. These experiments confirmed the stability of these catalytic materials in air up to $700{ }^{\circ} \mathrm{C}$. The catalytic evaluations carried out at high space velocities showed the suitability of these supported catalysts for applications with 


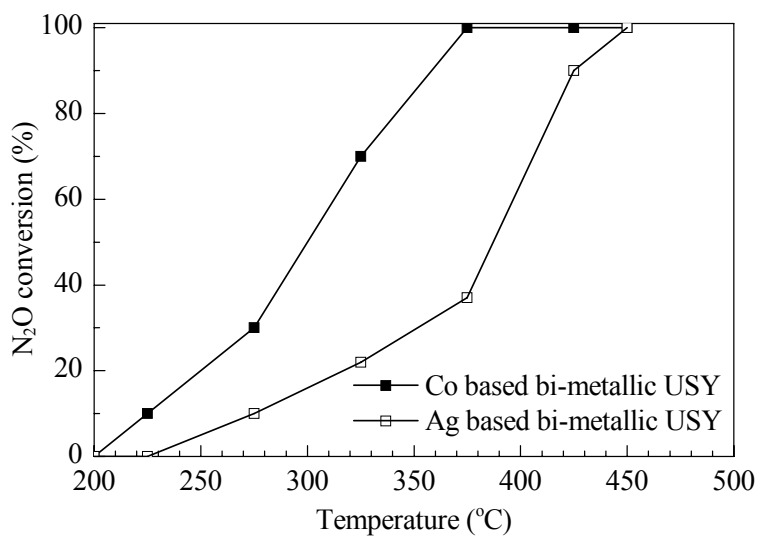

Fig. 6. Catalytic activity of bimetallic USY zeolite catalyst for $\mathrm{N}_{2} \mathrm{O}$ decomposition reaction. Reaction conditions: $0.5 \% \mathrm{~N}_{2} \mathrm{O}$, He balance, space velocity $36000 \mathrm{~h}^{-1}$.

Table 1 TG results for catalytic carbon/soot oxidation [35]

\begin{tabular}{lccc}
\hline Sample & $T_{\mathrm{i}} /{ }^{\circ} \mathrm{C}$ & $T_{50 \%} /{ }^{\circ} \mathrm{C}$ & $T_{\mathrm{f}} /{ }^{\circ} \mathrm{C}$ \\
\hline Bare carbon & 400 & 560 & 620 \\
Zirconia + soot & 400 & 560 & 620 \\
Bimetallic oxide/zirconia+soot & 310 & 460 & 530 \\
\hline
\end{tabular}

$T_{\mathrm{i}}$-initial temperature of soot oxidation;

$T_{\mathrm{f}}$-final temperature of soot oxidation.

high space velocity requirements. We are further working on supporting these catalysts on a new generation of high surface area supports including mesoporous materials, which offer very high surface areas as well as better mass transfer rates due to the larger pore size.

\section{Low cost template based synthesis of mesoporous ceramic materials}

We have been working on the development of low cost templating methods to synthesize a variety of ceramic and other materials with mesoporous properties and high surface areas. Low cost biopolymer and other natural materials were used to synthesize these materials. Many of these synthesized materials do not have an ordered structure. However, their pore characteristics and high surface areas indicated that they would be very useful as a support for many catalysts. These unordered mesoporous materials can be synthesized by precipitation and combustion synthesis routes. In a typical co-precipitation method, a natural biopolymer, chitosan, was dissolved in 5\% $(v / v)$ acetic acid with constant stirring. An aqueous salt solution of precursor was subsequently added to the biopolymer slurry with vigorous stirring for $2 \mathrm{~h}$. This precursor was then subjected to the following: a) precipitation in $50 \%$ ammonia solution, drying at ambient temperature and then calcined at the desired temperature, and b) drying at $60{ }^{\circ} \mathrm{C}$ followed by calcination at
$400{ }^{\circ} \mathrm{C}$ for $4 \mathrm{~h}$ as described in our publication [41]. In the combustion method, the metal-chitosan precursor obtained in the above process was placed in a preheated furnace at the respective temperatures of calcination. After a short drying phase, the explosion reaction quickly resulted in a highly porous and foamy material. We were able to synthesize a range of materials by this method, including alumina, ceria, zirconia, titania, and even perovskites [42]. These different supports have been synthesized by manipulating the chitosan:metal ratio, synthesis temperature, and heating atmosphere.

\subsection{Characterization of support materials synthesized by the template method}

The synthesized materials were characterized using XRD and BET-SA investigations. Figure 7(1) illustrates the XRD patterns of the synthesized mesoporous $\mathrm{Al}_{2} \mathrm{O}_{3}$ [43]. The $\mathrm{XRD}$ analysis showed the formation of an alumina phase with the presence of the characteristic XRD peaks for the $\gamma-\mathrm{Al}_{2} \mathrm{O}_{3}$ phase sample as discussed elsewhere [43]. The XRD pattern of the synthesized ceria is shown in Fig. 7(3). The cerium oxide samples showed the crystalline fluorite structure as indicated by comparison with the JCPDS database The synthesized mesoporous $\mathrm{TiO}_{2}$ was the anatase phase (Fig. 7(2)) [16]. A tetragonal phase was observed for the synthesized mesoporous $\mathrm{ZrO}_{2}$ sample as demonstrated by the XRD pattern (Fig. 7(4)) [42]. The low angle XRD peaks $\left(1^{\circ}-3^{\circ}\right)$ characteristic of an ordered mesoporous structure were not observed for any of these synthesized supports [44]. This implied that an ordered mesoporous structure was not formed for these materials, which was also expected by considering the template (chitosan) used for the synthesis. The predominant crystalline chitosan peaks at $8^{\circ}$, $20^{\circ}$, and $29^{\circ}$ were not observed [45], which showed that the

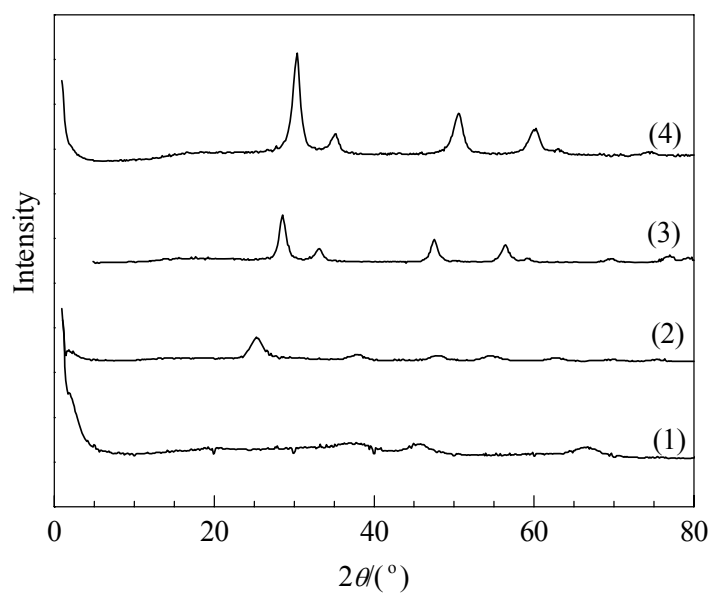

Fig. 7. XRD patterns of mesoporous $\mathrm{Al}_{2} \mathrm{O}_{3}(1)$, mesoporous $\mathrm{TiO}_{2}(2)$, mesoporous $\mathrm{CeO}_{2}$ (3), and mesoporous $\mathrm{ZrO}_{2}$ (4). 
organic matter has been eliminated after the formation of the metal oxides.

The specific surface area and pore size determined by the BJH method for the synthesized catalyst supports using the low cost biopolymer are presented in Table 2 . The $\mathrm{N}_{2}$ specific surface area of mesoporous alumina was $312 \mathrm{~m}^{2} / \mathrm{g}$, with an average pore size of $4.27 \mathrm{~nm}$ [42]. The specific surface area of the mesoporous ceria was $144.2 \mathrm{~m}^{2} / \mathrm{g}$ with an average pore diameter of $3.24 \mathrm{~nm}$ as detailed in our recent publication [41]. The specific surface area and pore size of the synthesized mesoporous titania and zirconia (Table 2) were $130 \mathrm{~m}^{2} / \mathrm{g}, 32.97 \mathrm{~nm}$ and $34.91 \mathrm{~m}^{2} / \mathrm{g}, 35.5 \mathrm{~nm}$, respectively [42]. These results clearly demonstrated that the synthesized supports were mesoporous and possessed high surface areas.

Table 2 Surface area and pore size of mesoporous alumina, titania, ceria and zirconia [42]

\begin{tabular}{lc}
\hline Mesoporous sample & Specific surface area $\left(\mathrm{m}^{2} / \mathrm{g}\right)$ \\
\hline $\mathrm{Al}_{2} \mathrm{O}_{3}$ & 312 \\
$\mathrm{TiO}_{2}$ & 130 \\
$\mathrm{CeO}_{2}$ & 144 \\
$\mathrm{ZrO}_{2}$ & 35 \\
\hline
\end{tabular}

\subsection{Catalytic $\mathrm{CO}$ oxidation activity of mesoporous $\mathrm{Al}_{2} \mathrm{O}_{3}, \mathrm{CeO}_{2}, \mathrm{TiO}_{2}$, and $\mathrm{ZrO}_{2}$}

These mesoporous materials were studied for their $\mathrm{CO}$ oxidation activity using a steady state evaluation assembly equipped with a quartz reactor, precise mass flow controllers and a heating system. The catalyst $(100 \mathrm{mg})$ was loaded in the reactor. The catalyst was pre-treated in He flow. A reactant gas containing $0.2 \% \mathrm{CO}, 10 \% \mathrm{O}_{2}$, and He balance was used for $\mathrm{CO}$ oxidation and catalytic activity was measured at two different space velocities. The detector was a Shimadzu gas chromatograph with molecular sieve 5A and Porapak-Q columns and a TCD detector.

The support materials showed significant catalytic activity only above $300{ }^{\circ} \mathrm{C}$, except for mesoporous $\mathrm{CeO}_{2}$, which showed $\mathrm{CO}$ oxidation at lower temperatures. Therefore, efforts were made to synthesize different cerium oxide samples by varying the template to cerium mass ratio and calcination temperatures in order to improve the important physical properties such as porosity, particle size, and surface area. The catalytic activity in $\mathrm{CO}$ oxidation reaction has been reported in our previous publication [41]. Mesoporous ceria was also prepared by the so called combustion synthesis in which the ceria-metal solution was dried at $60{ }^{\circ} \mathrm{C}$ with subsequent calcination at $400-500{ }^{\circ} \mathrm{C}$ for 4-6 h. Commercial (laboratory grade) cerium oxide was used for reference comparison after it was oven dried at 100 ${ }^{\circ} \mathrm{C}$ for $4 \mathrm{~h}$.
The CO oxidation activity as a function of temperature is shown in Fig. 8 for the synthesized ceria samples and commercial ceria to study the relationship with their physical properties.

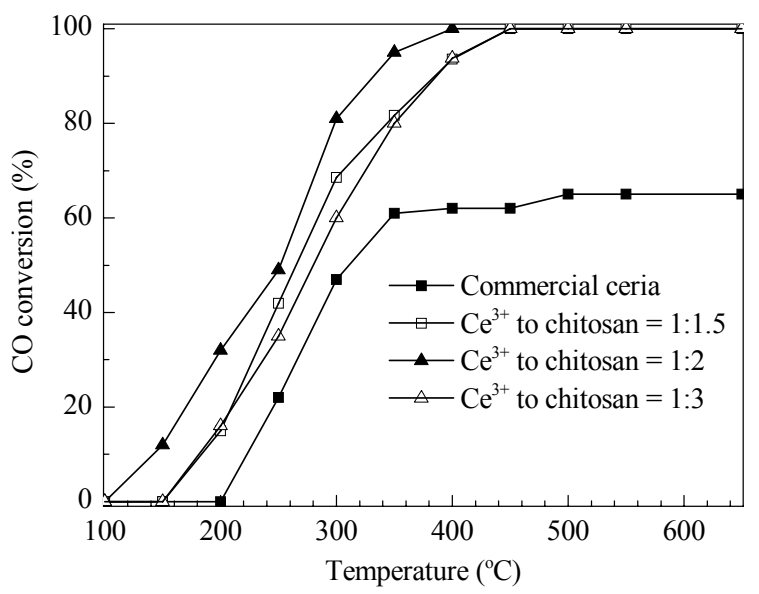

Fig. 8. CO conversion as a function of temperature for different ceria samples including commercial ceria. Reaction conditions: $0.2 \% \mathrm{CO}$, $20 \% \mathrm{O}_{2}$, He balance, space velocity $30000 \mathrm{~h}^{-1}$.

From the figure, it was clear that all the mesoporous ceria samples showed enhanced overall $\mathrm{CO}$ oxidation activity when compared with commercial ceria. CO oxidation (90\%) at $350{ }^{\circ} \mathrm{C}$ was observed at $30000 \mathrm{~h}^{-1}$ space velocity with the mesoceria sample, which was a much improved catalytic activity over that of bare ceria. The enhanced catalytic activity of the synthesized ceria samples was attributed to the increased surface area and pore dimensions.

\subsection{Cu-Mn based mixed oxide catalysts supported on mesoporous $\mathrm{Al}_{2} \mathrm{O}_{3}, \mathrm{CeO}_{2}, \mathrm{TiO}_{2}$, and $\mathrm{ZrO}_{2}$}

The catalytic activity of an active component can be influenced by both chemical and physical properties of the support including its chemical composition, porosity, particle size, and surface area. $\mathrm{Cu}-\mathrm{Mn}$ based bimetallic catalysts were synthesized that were supported on $\mathrm{Al}_{2} \mathrm{O}_{3}, \mathrm{CeO}_{2}, \mathrm{TiO}_{2}$, and $\mathrm{ZrO}_{2}$. These materials were studied for their $\mathrm{CO}$ oxidation activity as described elsewhere [44]

\subsection{Catalytic activity for CO oxidation}

The catalytic activity for $\mathrm{CO}$ oxidation was studied for these mixed oxide catalysts supported on a mesoporous ceramic. As described earlier, $\mathrm{Cu}-\mathrm{Mn}$ impregnated mesoporous $\mathrm{Al}_{2} \mathrm{O}_{3}$, mesoporous $\mathrm{ZrO}_{2}$ and mesoporous $\mathrm{TiO}_{2}$ show onset of $\mathrm{CO}$ oxidation activity at about $60{ }^{\circ} \mathrm{C}$ (Fig. 9) [42]. Among the catalysts of $\mathrm{Cu}-\mathrm{Mn}$ loaded on mesoporous $\mathrm{Al}_{2} \mathrm{O}_{3}$, on mesoporous $\mathrm{ZrO}_{2}$ and on mesoporous $\mathrm{TiO}_{2}$, that on mesoporous $\mathrm{ZrO}_{2}$ showed higher activity than the $\mathrm{TiO}_{2}$ 
and $\mathrm{Al}_{2} \mathrm{O}_{3}$ supported catalysts. Although mesoporous $\mathrm{Al}_{2} \mathrm{O}_{3}$ has a high specific surface area, this was not reflected in the catalytic activity. The $T_{\mathrm{i}}$ and $T_{50}$ of $\mathrm{Cu}-\mathrm{Mn} / \mathrm{ZrO}_{2}$ and $\mathrm{Cu}-\mathrm{Mn} / \mathrm{TiO}_{2}$ were lower than those of $\mathrm{Cu}-\mathrm{Mn} / \mathrm{Al}_{2} \mathrm{O}_{3}$. The bimetal supported catalysts followed the activity sequence of $\mathrm{Cu}-\mathrm{Mn} / \mathrm{ZrO}_{2}>\mathrm{Cu}-\mathrm{Mn} / \mathrm{TiO}_{2}>\mathrm{Cu}-\mathrm{Mn} / \mathrm{Al}_{2} \mathrm{O}_{3}$. The redox properties of $\mathrm{TiO}_{2}\left(\mathrm{Ti}^{+4}\right.$ to $\left.\mathrm{Ti}^{+3}\right)$ and $\mathrm{ZrO}_{2}\left(\mathrm{Zr}^{+4}\right.$ to $\left.\mathrm{Zr}^{+3}\right)$, which enhance oxygen mobility, were the probable reason for the better activity of $\mathrm{Cu}-\mathrm{Mn} / \mathrm{TiO}_{2}$ and $\mathrm{Cu}-\mathrm{Mn} / \mathrm{ZrO}{ }_{2}$, as discussed in our previous publication [42].

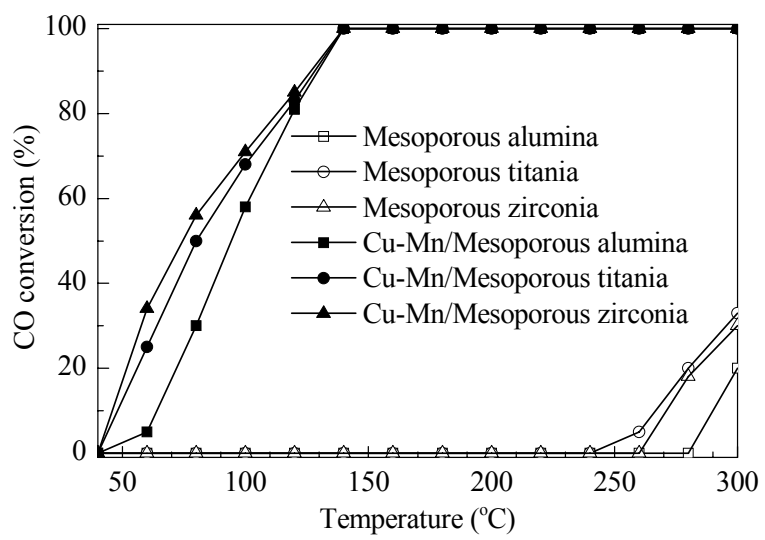

Fig. 9. $\mathrm{CO}$ oxidation over $\mathrm{Al}_{2} \mathrm{O}_{3}, \mathrm{TiO}_{2}, \mathrm{ZrO}_{2}, \mathrm{Cu}-\mathrm{Mn} /-\mathrm{Al}_{2} \mathrm{O}_{3}$, $\mathrm{Cu}-\mathrm{Mn} / \mathrm{TiO}_{2}$, and $\mathrm{Cu}-\mathrm{Mn} / \mathrm{ZrO}_{2}$. Reaction conditions: $0.2 \% \mathrm{CO}, 10 \%$ $\mathrm{O}_{2}$, He balance, space velocity $30000 \mathrm{~h}^{-1}$.

According to the experimental results of Gonzalo et al. [46], the decrease in activity of $\mathrm{Al}_{2} \mathrm{O}_{3}$ was due to the formation of the less active aluminate phase with the transition metals, while the redox and oxygen desorption properties of $\mathrm{TiO}_{2}$ and $\mathrm{ZrO}_{2}$ prevented the formation of titanates and zirconates with $\mathrm{Cu}$ and $\mathrm{Mn}$ under the present synthesis conditions [47-49]. Therefore, $\mathrm{Cu}-\mathrm{Mn}$ impregnated $\mathrm{TiO}_{2}$ and $\mathrm{ZrO}_{2}$ catalysts showed a superior activity to that of the $\mathrm{Cu}-\mathrm{Mn}$ impregnated $\mathrm{Al}_{2} \mathrm{O}_{3}$ catalyst.

\section{Ceramics for chemical looping combustion}

Ceramic materials are among the few options available for high temperature applications like chemical looping combustion (CLC) and other catalytic combustion processes. The stringent requirements of very high thermal stability (typically in the range of $800-1300{ }^{\circ} \mathrm{C}$ ), structural stability, and inert chemical nature are some of the demanding properties required for such applications. Although theoretically perovskites cannot be considered high oxygen capacity materials, their advantages in multiple cycle redox operations include their reversibility of structure, thermal stability, and catalytic activity, which are some of the useful properties that make them potential candidates as the oxygen carrier (OC) or CLC material. Ceria promoted perovskite was explored as an oxygen carrier. Methane was used as the combustion fuel [50]. A ceria promoted lantahanum based perovskite material displayed good and stable behaviour over the four reduction/re-oxidation cycles tested (Fig. 10). The methane combustion was carried out at $750{ }^{\circ} \mathrm{C}$ in a fuel reactor with a simulated gas mixture of $55 \%$ methane balanced by helium at a flow rate of 10 SCCM. The low concentration of methane was used to get a reliable breakthrough time and avoid the possibility of measurement error. The effluent stream was analyzed using a Shimadzu gas chromatograph equipped with a thermal conductivity detector (TCD). XRD and EDX results of used samples confirmed the chemical and structural stability of the oxygen carrier [50]. The mechanical property of material still needs to be studied for its use in a fluidized bed reactor. Other perovskite compositions are being explored for their oxygen carrying capacity under different reactions conditions of methane based chemical looping combustion.

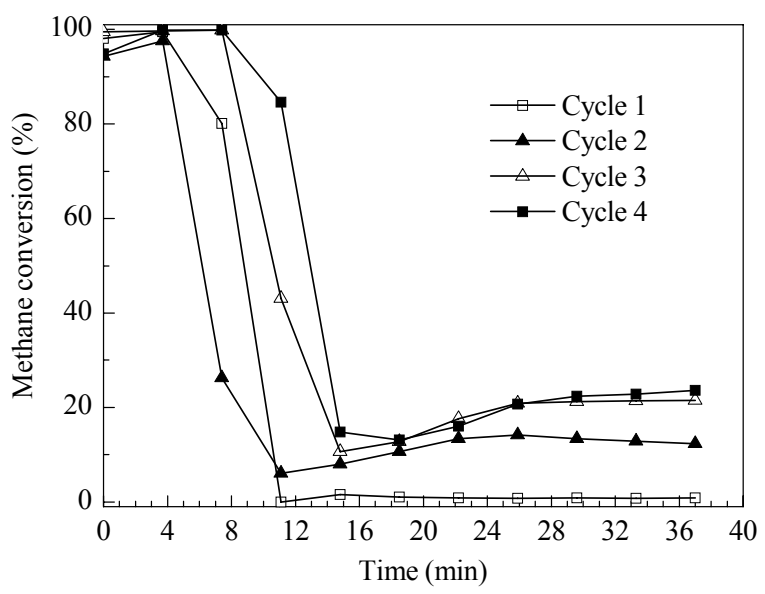

Fig. 10. Breakthrough curve for methane combustion on a perovskite type oxygen carrier for CLC reaction. Reaction conditions: $0.56 \% \mathrm{CH}_{4}$, He balance, space velocity $6000 \mathrm{~h}^{-1}$ [50].

The promoter effect of other elements on the perovskite and their stability in multiple cycles should be further studied.

\section{Enhanced carbonation reaction for $\mathrm{CO}_{2}$ sequestration}

Ceramic materials have proved to be good sinks for the sequestration of $\mathrm{CO}_{2}$, which is a major greenhouse gas responsible for global warming and its catastrophic environmental consequences. One potential way to sequester $\mathrm{CO}_{2}$ is to transform it into a carbonate mineral. Two commonly explored processes are mineral carbonation (chemical route) and bio-mineralization (bio-assisted route). These processes offer the possibility of locking the $\mathrm{CO}_{2}$ into the form of stable carbonates without excessive energy inputs. We have 
been working on both options for $\mathrm{CO}_{2}$ sequestration and one of the bio-catalysis based approaches is given here in more detail. In this process, the carbonic anhydrase enzyme was stabilized and transformed into "single enzyme nano-particles" to improve its activity and stability. The carbonic anhydrase (CA) enzyme was used to enhance the hydration of $\mathrm{CO}_{2}$ to bicarbonates, which was then further converted into a carbonate to give a stable and environmentally benign product. CA is a zinc based metallo-enzyme that is ubiquitous in nature. Each molecule of CA iso-enzyme can catalyze $1.4 \times 10^{6}$ molecules of $\mathrm{CO}_{2}$ in one second [51-53] by the reaction

$$
\mathrm{CO}_{2}+\mathrm{H}_{2} \mathrm{O} \stackrel{\mathrm{CA}}{\longleftrightarrow} \mathrm{H}^{+}+\mathrm{HCO}_{3}^{-}
$$

However, the short catalytic lifetime of $\mathrm{CA}$ limits its usefulness. Several approaches are pursued to improve the catalytic stability of the enzyme including enzyme immobilization, enzyme modification, protein engineering, and genetic modification. In the recent years, significant progress have been made on the issue of enzyme stability by creating modified forms of the enzyme, such as single enzyme nanoparticles (SENs) [54]. In the SENs, an enzyme molecule is modified by enclosing it in a cage formed by a porous organic/inorganic structure of less than a few nanometers. SENs of chymotrypsin and trypsin have been shown to have many advantages such as increased stability and activity, high surface area, performance at high temperatures, stability to denaturation and aggregation, and minimal mass transfer limitation and improved half life [55]. The synthesis of the SEN of carbonic anhydrase (SEN-CA) was performed by modifying the surface of each enzyme molecule with a hybrid organic/inorganic biopolymer silica network. By using a biopolymer, the catalytic efficiency was much stabilized compared with that of the free CA without imposing mass transfer limitation of the substrate. The transmission electron microscope (TEM) image of lyophilized SEN-CA was recorded by a Tecnai-F20 (FEI, The Netherlands). The lyophilized SEN-CA was dispersed in ethanol, and after $5 \mathrm{~min}$, the clear supernatant was dropped onto a $\mathrm{Cu}$ grid covered with carbon. The TEM images confirmed the presence of individual nanoparticles with a contrasting outer structure. This is shown in Fig. 11.

Figure 11 shows the TEM image of the SEN-CA. The hollow centers of the nanoparticles are due to the transparent core protein. The dark image surrounding the transparent core is the composite cross-linked biopolymer. Energy-dispersive X-ray analysis (EDX) confirmed the presence of zinc and silicon in the nanoparticle (Fig. 12). The average size of these SEN particles was 70-80 nm [56]. The carbonation study was carried out using the method described by Favre et al. [56] with a slight modification. The time required for the onset of the precipitation reaction and carbonate formation was monitored with the sample and a

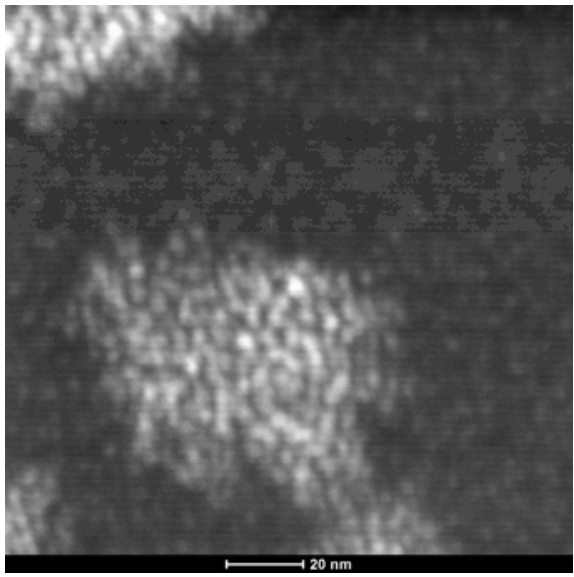

Fig. 11. TEM image of SEN.

control (without CA). The carbonate obtained was filtered and dried at $25{ }^{\circ} \mathrm{C}$. The quantity of carbonate precipitated was quantified by gas chromatography with a thermal conductivity detector (TCD). This eliminated the interference of other precipitate like calcium phosphate. The carbonate precipitate obtained was treated with $0.5 \mathrm{~mol} / \mathrm{L} \mathrm{HCl}$ and the evolution of $\mathrm{CO}_{2}$ was monitored using the GC. The evolved gas was collected in the collector and then analyzed in the GC/TCD using a Porapak Q column. For the storage stability study, free CA and SEN-CA were prepared in bulk and stored as aliquots at $4{ }^{\circ} \mathrm{C}$ for $30 \mathrm{~d}$. The carbonation capacity was determined at $5 \mathrm{~d}$ intervals.

In the precipitation reaction, the time recorded for the onset of carbonate precipitate in the sample with the SEN-CA was $37 \mathrm{~s}$ as compared with $170 \mathrm{~s}$ in the blank without CA. With free CA, it was $20 \mathrm{~s}$. The result established the concept that the SEN-CA was instrumental in accelerating the carbonation reaction. Sequestration capacity of $147 \mathrm{mg}$ of $\mathrm{CaCO}_{3}$ per mg of CA content was observed for SEN-CA, as compared with $35 \mathrm{mg}$ of $\mathrm{CaCO}_{3}$ per $\mathrm{mg}$ of CA for free $\mathrm{CA}$, at $\mathrm{CO}_{2}$ concentration of $0.1257 \mathrm{mg}$ per $10 \mathrm{ml}$. There was an improvement in the storage stability with SEN-CA as compared with free CA. It was observed that the SEN-CA retained a significant degree of its initial carbona-

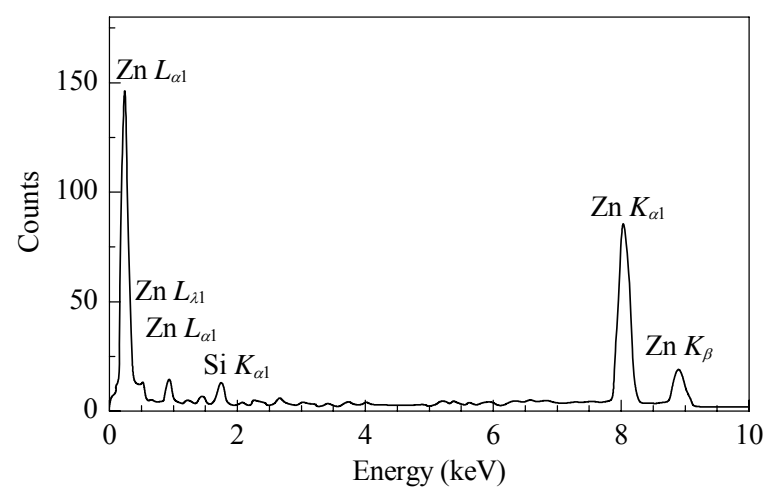

Fig. 12. EDX analysis confirming the presence of zinc in the SEN. 
tion capacity for several days $[56,57]$.

\section{Conclusions}

Ceramic materials and processes are important in many environmental applications including environmental catalysis. Ceramics have many applications in environmental processes, while their application as catalyst supports is of great significance. Although remarkable improvements have been achieved in ceramic materials and processing, this area is still fast developing because of new applications like chemical looping combustion (CLC). Cordierite-based honeycomb catalyst supports have been a great success in automobile and stationary applications, and this area has witnessed continuous advances. The development of improved diesel particulate filters is still receiving much attention due to its predicted widespread application in the near future. The development of new and improved ceramic materials with a mesoporous structure and high surface area offer new possibilities for various catalytic reactions. The preparation of mesoporous perovskites is also important. By proper modifications, it is possible to prepare suitable ceramic supports for perovskite catalysts, and also possible to develop processes to support various materials on improved supports. The recent demand for non-noble metal based catalysts for automobile exhaust and other applications including CLC reactions is leading to new innovations in ceramic supports and ceramic type materials. Ceramics are also playing an important role in $\mathrm{CO}_{2}$ (carbon dioxide) capture and sequestration, and carbonates are being explored as a safe form of $\mathrm{CO}_{2}$ storage. For these new applications, continued $R \& D$ efforts are required to exploit the remarkable potential of ceramic materials.

\section{Acknowledgements}

This research work has been carried out under the DST sponsored project (SR/S3/CE/095/2009) and NEERI-NIMS research collaboration. Authors would also like to thank Director NEERI-CSIR for providing the necessary facilities for most the work reported in this paper.

\section{References}

1 Bardhan P. Curr Opin Solid State Mater Sci, 1997, 2: 577

2 Armor J N. Chem Mater, 1994, 6: 730

3 Williams J L. Catal Today, 2001, 69: 3

4 Heck R M, Farrauto R J. Catalytic Air Pollution Control Commercial Technology. 2nd Ed. New York: John Wiley \& Sons, 2002

5 Sebastian V, Mallada R, Coronas J, Julbe A, Terpstra R A, Dirrix R W J. J Membr Sci, 2010, 355: 28
6 Granato T, Katovic A, Valkaj K M, Zrncevic S. Stud Surf Sci Catal, 2008, 174: 1171

7 Silva E, Catalão R, Silva J, Vaz F, Oliveira F, Ribeiro F R, Magnoux P, Belin T, Ribeiro F. Stud Surf Sci Catal, 2008, 174: 1195

8 Cerri I, Saracco G, Specchia V. Catal Today, 2000, 60: 21

9 Okada A. J Eur Ceram Soc, 2008, 28: 1097

10 Oi-Uchisawa J, Obuchi A, Wang S, Nanba T, Ohia A. Appl Catal B, 2003, 43: 117

11 Chen X Z, Liu H F, Wei Y Y, Jurgen C, Haihui W. J Alloys Compd, 2009, 484: 386

12 Arendt E, Maione A, Klisinska A, Sanz O, Montes O S M, Suarez S, Blanco J, Ruiz P. Appl Catal A, 2008, 339: 1

13 Gan B K, Yao K. Ceram Int, 2009, 35: 2061

14 Ling Y H, Lin B, Zhao L, Zhang X Z, Yu J, Peng R, Meng G Y, Liu X Q. J Alloys Compd, 2010, 493: 252

15 Labhsetwar N K, Watanabe A, Biniwale R B, Kumar R, Mitsuhashi T. Appl Catal B, 2001, 33: 165

16 Joshi M M, Labhsetwar N K, Mangrulkar P A, Tijare S N, Kamble S P, Rayalu S S. Appl Catal A, 2009, 357: 26

17 Labhsetwar N, Dhakad M, Biniwale R, Mitsuhashi T, Haneda H, Reddy P S S, Bakardjieva S, Subrt J, Kumar S, Kumar V, Saiprasad P, Rayalu S. Catal Today, 2009, 141: 205

18 Kumar S, Rayalu S, Russo N, Kanade G S, Kusaba H, Teraoka Y, Labhsetwar N. Catal Lett, 2009, 132: 248

19 Prabhu C, Wanjari S, Gawande S, Das S, Labhsetwar N, Kotwal S, Puri A K, Satyanarayana T, Rayalu S. J Mol Catal B, 2008, 5: 8

20 Olajire A A. Energy, 2010, 35: 2610

21 Thiruvenkatachari R, Su S, An H, Yu X X. Prog Energy Combust Sci, 2009, 35: 438

22 Alshebani A, Pera-Titus M, Landrivon E, Schiestel T H, Miachon S, Dalmon J A. Microporous Mesoporous Mater, 2008, 115: 197

23 Pena M A, Fierro J L G. Chem Rev, 2001, 101: 1981

24 Nishihata Y, Mizuki J, Akao T, Tanaka H, Uenishi M, Kimura M, Okamoto T, Hamadak N. Nature, 2002, 418: 132

25 Hackermueller L, Schneider U, Moreno-Cardoner M, Kitagawa T, Best T, Will S, Demler E, Altman E, Bloch I, Paredes B. Science, 2010, 327: 1621

26 Grillo F, Natile M M, Glisenti A. Appl Catal B, 2004, 48: 267

27 Deng H B, Lin L, Sun Y, Pang C S, Zhuang J P, Ouyang P, Li J J, Liu S J. Energy Fuels, 2009, 23: 19

28 Teraoka Y, Yoshimatsu M, Yamazone N, Seiyama T. Chem Lett, 1984: 893

29 Blasin-Aubé V, Belkouch J, Monceaux L. Appl Catal B, 2003, 43: 175

30 Biniwale R B, Bawase M A, Labhsetwar N K, Kumar R. Ind J Chem A, 2003, 42: 1833

31 Labhsetwar N, Watanabe A, Mitsuhashi T. US Patent 2002-0114752

32 Labhsetwar N, Biniwale R B, Kumar R, Rayalu S, Devotta S. Catal Surv Asia, 2006, 10: 55

33 Labhsetwar N K, Watanabe A, Mitsuhashi T. Appl Catal B, 2003, 40: 21 
34 Labhsetwar N K, Watanabe A, Mitsuhashi T, Haneda H. J Mol Catal A, 2004, 223: 217

35 Dhakad M, Fino D, Rayalu S S, Kumar R, Watanabe A, Haneda H, Devotta S, Mitsuhashi T, Labhsetwar N. Top Catal, 2007, 42-43: 273

36 Labhsetwar N, Doggali P, Chankapure P, Vallecha D, Lokhande S, Watanabe A, Rayalu S, Haneda H, Mitsuhashi T. Top Catal, 2009, 52: 1909

37 Dhakad M, Rayalu S S, Kumar R, Doggali P, Bakardjieva S, Subrt J, Mitsuhashi T, Haneda H. Catal Lett, 2008, 121: 137

38 Dhakad M, Rayalu S, Subrt J, Bakardjieva S, Mitsuhashi T, Haneda H, Devotta S, Labhsetwar N. Curr Sci, 2007, 92: 1128

39 Doggali P, Kusaba S, Teraoka Y, Chankapure P, Rayalu S, Labhsetwar N. Catal Commun, 2010, 11: 665

40 Cimino S, Lisi L, Pirone R, Russo G, Turco M. Catal Today, 2000, 59: 19

41 Valechha D, Lokhande S, Klementova M, Subrt J, Rayalu S, Labhsetwar N. J Mater Chem, 2011, 21: 3718

42 Doggali P, Kusaba H, Einaga H, Bensaid S, Rayalu S, Teraoka Y, Labhsetwar N. J Hazard Mater, 2010, 186: 796

43 Fajardo H V, Martins A O, de Almeida R M, Noda L K, Probst L F D, Carreno N L V, Valentini A. Mater Lett, 2005, 59: 3963

44 Fei H L, Liu Y Q, Li Y P, Sun P C, Yuan Z Y, Li B H, Ding D
T, Chen T H. Microporous Mesoporous Mater, 2007, 102: 318

45 Kamble S P, Jagtap S, Labhsetwar N K, Thakare D, Godfrey S, Devotta S, Rayalu S S. Chem Eng J, 2010, 129: 173

46 Gonzalo A, Francisco G, Paulo A. Appl Catal A, 2008, 343: 16

47 Dow W P, Huang T J. J Catal, 1994, 147: 322

48 Zhou R X, Jiang X Y, Mao J X, Zheng X M. Appl Catal A, 1997, 162: 213

49 Robert M F, John J F, Farrel W L. J Catal, 1978, 55: 10

50 Valechha D, Patil A, Rayalu S, Teraoka Y, Labhsetwar N. J Novel Carbon Resource Sci, 2011, 4: 13

51 Bond G M, Stringer J, Brandvold D K, Simsek F A, Medina M G, Egeland G. Energy Fuels, 2001, 15: 309

52 Bhattacharya S, Nayak A, Schiavone M, Bhattacharya S K. Biotechnol Bioeng, 2004, 86: 37

53 Favre N, Christ M L, Pierre A C. J Mol Catal B, 2009, 60: 163

54 Kim J, Grate J W. Nano Lett, 2003, 3: 1219

55 Kim J, Jia H, Lee C W, Chung S W, Kwak J H, Shin Y, Dohnalkova A, Kim B G, Wang P, Grate J W. Enzyme Microb Technol, 2006, 39: 474

56 Yadav R, Labhsetwar N, Kotwal S, Rayalu S. J Nanopart Res, 2011, 13: 263

57 Yadav R, Satyanarayana T, Kotwal S, Rayalu S. Curr Sci, 2011, 3: 520 